\title{
Data recovery of $\mathrm{A} 06$ and $\mathrm{A} 07$ WOCE cruises
}

\section{N. M. Fajar, F. F. Pérez, A. Velo, and A. F. Ríos}

Instituto de Investigaciones Marinas de Vigo (IIM-CSIC), C/Eduardo Cabello,

6. Vigo, Pontevedra, 36208, Spain

Received: 10 October 2011 - Accepted: 11 October 2011 - Published: 21 October 2011

Correspondence to: N. M. Fajar (nfajar@iim.csic.es)

Published by Copernicus Publications.

Data recovery of A06 and $A 07$ WOCE cruises

N. M. Fajar et al.

\section{Title Page}

Abstract Instruments

Data Provenance \& Structure

Tables

Figures

14

$>1$

4

$>$

Back Close

Full Screen / Esc

Printer-friendly Version

Interactive Discussion

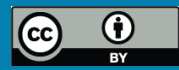




\section{Abstract}

The WOCE cruises were carried out during the 1990s and were included in GLODAP, which is an easily usable, available and fully calibrated global database. $A_{T}$ and $C_{T}$ data, together with the rest of carbon variables, were subjected to rigorous quality con5 trol and some adjustments were done assuming biases, in case of $A_{T}$ and $C_{T}$, not greater than $\pm 6 \mu \mathrm{mol} \mathrm{kg}^{-1}$ and $\pm 4 \mu \mathrm{mol} \mathrm{kg}^{-1}$, respectively. The A06 and A07 cruises were deleted from GLODAP database owing to $A_{T}$ and $C_{T}$ data were not suitable for analysis. However, these data are still available in CLIVAR and Carbon Hydrographic Data Office web site, demonstrated the unreliable quality of $A_{T}$ and $C_{T}$, but contrarily, 10 the more realistic profiles of $\mathrm{pH}$ data. The main goal of the present work is to recover $\mathrm{A}_{\mathrm{T}}$ and $\mathrm{C}_{\mathrm{T}}$ data of $\mathrm{A} 06$ and $\mathrm{A} 07$ using GLODAP database combining with CARINA database and the most contemporary cruise $M O C^{2}$ Equatorial 2010. Thus, $A_{T}$ data of A06 and A07 will be renewed using directly these data in a particular application of Multiple Linear Regression: the 3-D moving window MLR estimation method. Moreover,

${ }_{15} \quad \mathrm{C}_{\mathrm{T}}$ data will be recalculated using the $\frac{\mathrm{C}_{\mathrm{T}}}{\mathrm{A}_{\mathrm{T}}}$ ratio together with the obtained results from the crossovers analysis method. In order to demonstrate the quality of the recovered $A_{T}$ and $C_{T}$, the new $\mathrm{pH}$ has been calculated, showing the good agreement in terms of $\mathrm{pH}$ obtained between $\mathrm{A} 06$ and $\mathrm{A} 07$ related to $\mathrm{MOC}^{2}$. To sum up, the entire carbon databases of $\mathrm{A} 06$ and $\mathrm{A} 07$ were checked and recovered.

\section{Introduction}

The World Ocean Circulation Experiment (WOCE) together with the Joint Global Ocean Flux Study (JGOFS), and the Ocean-Atmosphere Carbon Exchange Study (OACES) were carried out during the 1990s. The three programs covered different ocean regions, improving the combined global coverage. The collaborative efforts between scientists concluded in the known Global Ocean Data Analysis Project (GLODAP) (Sabine et al., 2005) as an easily usable and fully calibrated global database. Between the general goals of GLODAP, it is worth highlighting the distribution of the variables of 100
ESSDD

4, 99-122, 2011

Data recovery of A06 and A07 WOCE cruises

N. M. Fajar et al.

Title Page

Abstract Instruments

Data Provenance \& Structure

Tables $\quad$ Figures

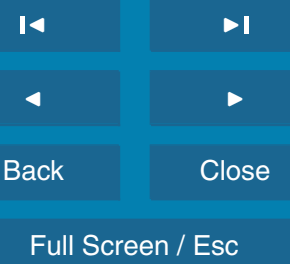

Printer-friendly Version Interactive Discussion

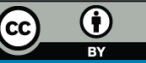


carbon system in order to estimate their changes and the possibility of evaluate the inventory of natural and anthropogenic carbon (Key et al., 2004). Thus, the data were merged into a common format database divided by ocean, which is available in the GLODAP website hosted by the Carbon Dioxide Information Analysis Center (CDIAC) 5 (http://cdiac.ornl.gov/oceans/glodap/index.html).

In the Atlantic Ocean, not only there are several cruises merged in GLODAP (Key et al., 2004) database but also in CARbon IN the Atlantic Ocean (CARINA) (Key et al., 2010). CARINA database was generated in order to create a merged calibrated database from open ocean measurements of biogeochemical investigations, in partic10 ular, studies involving the carbon system. The wide set of historical and recent hydrographic cruises include the entire Atlantic, the Artic and Southern Ocean giving one CARINA data product for each region. The CARINA products and a significant volume of supporting information are available in the CARINA web site also hosted by CDIAC (http://cdiac.ornl.gov/oceans/CARINA/). Despite the fact that the CARINA data prod15 ucts are compatible with the GLODAP data products, they are not identical, differing in column order, included parameters and number of data. Thus, in order to obtain a complete database, historical and recent cruises have been taken from both GLODAP and CARINA databases in the present work.

One key point in both GLODAP and CARINA databases is that an extensive calibration and quality control procedures have been designed to remove measurement bias and bad data in the carbonate system measurements sampled during the cruises involved in CARINA and GLODAP. The carbonate system in seawater describes the equilibrium between dissolved $\mathrm{CO}_{2}$ and carbonate and is defined by four parameters, i.e. total inorganic carbon $\left(\mathrm{C}_{\mathrm{T}}\right)$, total alkalinity $\left(\mathrm{A}_{\mathrm{T}}\right)$, $\mathrm{pH}$ and fugacity of $\mathrm{CO}_{2}\left(f \mathrm{CO}_{2}\right)$.

25 Knowing at least two of these parameters allows calculating the unknowns. Only $A_{T}$ and $\mathrm{C}_{\mathrm{T}}$ data, focused on the Equatorial Atlantic Ocean, will receive the whole attention hereinafter, being their biases, assumed by both GLODAP and CARINA databases, not greater than \pm 6 and $\pm 4 \mu_{\mathrm{mol} \mathrm{kg}}{ }^{-1}$ for $A_{T}$ and $C_{T}$, respectively (Key et al., 2004, 2010).

\section{ESSDD}

4, 99-122, 2011

Data recovery of A06 and A07 WOCE cruises

N. M. Fajar et al.

Title Page

Abstract Instruments

Data Provenance \& Structure

Tables $\quad$ Figures

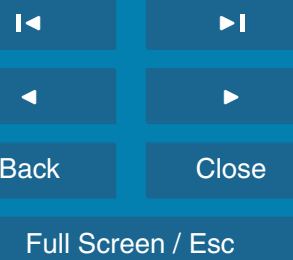

Printer-friendly Version Interactive Discussion 
The combined GLODAP + CARINA database contains bottle and carbon data from surface to deep ocean waters in the Atlantic Ocean from historical and recent cruises. In order to complete this combined database and to contribute with more modern data, the most contemporary cruise in the equatorial Atlantic Ocean is included in that 5 study: MOC $^{2}$ Equatorial (Meridional Overturning Circulation - Memoria Oceánica del Clima, http://www.icm.csic.es/oce/ca/content/moc2/), hereafter $\mathrm{MOC}^{2}$. MOC ${ }^{2}$ cruise was spanned along $7.5^{\circ} \mathrm{N}$ during April-May in 2010 on board of BIO Hespérides. Carbon system water samples, i.e. $\mathrm{C}_{\mathrm{T}}, \mathrm{A}_{\mathrm{T}}$ and $\mathrm{pH}$, have been sampled and analysed in the whole water column.

10 The A06 (Oudot, 1993a) and A07 WOCE (Oudot, 1993b) cruises were carried out on board of N/O l'Atalante as part of the French CITHER project. A07 took place in January 1993 along $4.5^{\circ} \mathrm{S}$ while A06 took place in February-March 1993 along $7.5^{\circ} \mathrm{N}$. The $A_{T}$ and $C_{T}$ data of both cruises were deleted from GLODAP database because these data were not suitable for analysis (Wanninkhof et al., 2003). However, these 15 data are still available in CLIVAR and Carbon Hydrographic Data Office (CCHDO) web site (http://cchdo.ucsd.edu/) inside the Atlantic Ocean data section. Thus, taking into account the combined GLODAP + CARINA + MOC ${ }^{2}$ database, the complete database of $A 06$ and $A 07$ cruises can be objectively revised and corrected.

Despite the fact that the $A_{T}$ and $C_{T}$ values of $A 06$ and $A 07$ cruises are out of quality 20 controls of CARINA and GLODAP, the calculated $\mathrm{pH}$ data, involving these $\mathrm{A}_{\mathrm{T}}$ and $\mathrm{C}_{\mathrm{T}}$, seem to show realistic and reliable profiles, as it can be seen in Fig. 1. In this figure, the $\mathrm{pH}$ profiles of $\mathrm{A06}, \mathrm{AO}$ and $\mathrm{MOC}^{2}$ cruises are shown, observing the coherence between $\mathrm{A} 06$ and $\mathrm{A} 07$ profiles related to $\mathrm{MOC}^{2} \mathrm{pH}$ profile. The relevance of this good agreement among cruises is that the combination of $A_{T}$ and $C_{T}$, in spite of being un25 reliable data, produces suitable $\mathrm{pH}$ results, hence, the ratio $\frac{\mathrm{C}_{T}}{\mathrm{~A}_{T}}$ is valid. Taking into account not only that there are many stations or even cruises driven close in time and location to A06 and A07 cruises (Fig. 2) but also the suitability of calculated pH data together with the validity of the $\frac{C_{T}}{A_{T}}$ ratio, the possibility of recovery the $A_{T}$ and $C_{T}$ data of $\mathrm{A} 06$ and a07 cruises, is planned as main aim of the present manuscript. Bear in
ESSDD

4, 99-122, 2011

Data recovery of A06 and A07 WOCE cruises

N. M. Fajar et al.

Title Page

Abstract Instruments

Data Provenance \& Structure

Tables $\quad$ Figures

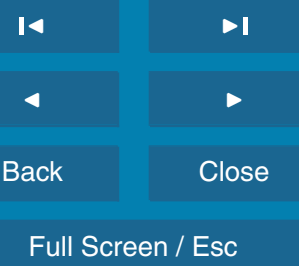

Printer-friendly Version Interactive Discussion

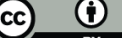


mind that $A_{T}$ is the parameter of the carbonic system with less variability, $A_{T}$ data $A 06$ and $A 07$ will be used directly in a 3-DwMLR method (Velo et al., 2011). Moreover, $C_{T}$ data will be checked and complete using the $\frac{C_{T}}{A_{T}}$ ratio and reassert the obtained $A_{T}$ and $\mathrm{C}_{\mathrm{T}}$ results using crossovers analysis (Tanhua, 2010). To sum up, the entire carbon 5 databases of $\mathrm{A} 06$ and $\mathrm{A} 07$ will be tested and recovered.

\section{Data}

Data of GLODAP and CARINA databases were widely revised and involved in different quality control processes in order to assure the highest veracity and consistency to their included measurements. Thus, carbon data of cruises of the Atlantic Ocean merged in oceans/). Table 1 shows all the cruises selected in this work including A06 and A07 cruises, specifying cruise number, expocode, alias, database to which belong each cruise, year and, in the last column, if the defined cruise was carried out near A06, A07 or both of them. The geographical distribution of these cruises is showed in Fig. 2, where the entire Atlantic Ocean basin is represented.

Databases of A06 and A07 cruises are available in CCHDO web site (http://cchdo. ucsd.edu/). A06 and A07 cruises were carried out in the winter season along $7.5^{\circ} \mathrm{N}$ and $4.5^{\circ} \mathrm{S}$, respectively, sampling and analysing some variables that defined the carbon system, i.e. $\mathrm{pH}$ and $\mathrm{C}_{\mathrm{T}}$. Measurements of $\mathrm{C}_{\mathrm{T}}$ were made by gas chromatography according to the modified method as described in Oudot et al. (1995). pH measurements were based on the total hydrogen ion concentration scale $\left(\mathrm{pH}_{\mathrm{sws}}\right)$ using a Ross combination electrode calibrated in Tris buffer. Because of the unknown temperature and calibration data of $\mathrm{pH}$ data of $\mathrm{A} 06$ and A07 cruises (Wanninkhof, 2003), in the present work the $\mathrm{pH}$ data were calculated from $\mathrm{A}_{\mathrm{T}}$ and $\mathrm{C}_{\mathrm{T}}$ using the Excel $\mathrm{CO}_{2}$ sys program (Pierrot et al., 2006) (http://cdiac.ornl.gov/ftp/co2sys/CO2SYS_calc_XLS/) and the acid constants from Mehrbach et al. (1973) fitted by Dickson and Millero (1987) together with the boron to chlorinity ratio from Lee et al. (2010). The $A_{T}$ data of cruises A06

\section{ESSDD}

4, 99-122, 2011

Data recovery of A06 and A07 WOCE cruises

N. M. Fajar et al.

Title Page

Abstract Instruments

Data Provenance \& Structure

Tables $\quad$ Figures

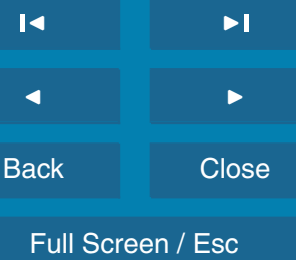

Printer-friendly Version

Interactive Discussion 
and $\mathrm{A} 07$ collected in the $\mathrm{CCHDO}$ were determined from $\mathrm{C}_{\mathrm{T}}$ and $\mathrm{pH}$ measurements using the equation describing the terms of alkalinity contributions defined by UNESCO (Oudot et al., 1995).

$\mathrm{MOC}^{2}$ cruise was carried out at spring season along $7.5^{\circ} \mathrm{N}$ in 2010 on board of 5 BIO Hespérides. This 2010 cruise is very close repetition of the leg spanned along $7.5^{\circ} \mathrm{N}$ by the cruise A06 in 1993 (see geographical location of A06 in Fig. 2). $A_{T}$ and $\mathrm{pH}$ samples have been analysed in the progression of the cruise, and the $\mathrm{C}_{\mathrm{T}}$ samples data were analysed in the laboratory of IIM-CSIC (Vigo). Measurements of $A_{T}$ were done by a one endpoint method using an automatic potentiometric titrator 10 with a combined glass electrode (Mintrop et al., 2000), in which the potentiometric titration was carried out using the two $\mathrm{pH}$ endpoints method according to Pérez and Fraga (1987). Seawater $\mathrm{pH}$ measurements were made using the spectrophotometric method described in Clayton and Byrne (1993) adding m-cresol purple as indicator and controlling the temperature at $25^{\circ} \mathrm{C}$ by a thermostatic bath. The $\mathrm{pH}$ scale fixed 15 in $\mathrm{MOC}^{2}$ was the total scale $\left(\mathrm{pH}_{\mathrm{T}}\right)$, but, with the aim of normalized $\mathrm{pH}$ data, $\mathrm{MOC}^{2}$ $\mathrm{pH}_{\mathrm{T}}$ were rescaled to $\mathrm{pH}_{\mathrm{SWs}}$ using the $\mathrm{CO}_{2}$ sys program. $\mathrm{C}_{\mathrm{T}}$ data were calculated from $A_{T}$ and $\mathrm{pH}$ using the $\mathrm{CO}_{2}$ sys program because there were not $\mathrm{C}_{\mathrm{T}}$ measured in the whole levels of the water column. The coulometric $C_{T}$ measured (Johnson et al., 1993, 1998 ) is relevant to check if the calculated $C_{T}$ fits well with measured $C_{T}$, observing a good consistence between them. In order to estimate the accuracy of the $A_{T}$ and $C_{T}$ methods, calibrations were performed with certified reference material $(\mathrm{CRM})$ of $\mathrm{CO}_{2}$ provided by Andrew Dickson.

\section{Methodology}

As previously said, the $A_{T}$ and $C_{T}$ of $A 06$ and $A 07$ cruises were deleted from GLODAP 25
ESSDD

4, 99-122, 2011

Data recovery of A06 and A07 WOCE cruises

N. M. Fajar et al.

Title Page

Abstract Instruments

Data Provenance \& Structure

Tables $\quad$ Figures

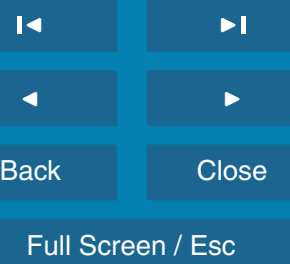

Printer-friendly Version

Interactive Discussion duces suitable $\mathrm{pH}$ results, being the $\frac{\mathrm{C}_{T}}{\mathrm{~A}_{T}}$ ratio valid. Therefore, the main phases of the present work were outlined. (1) Due to the low $A_{T}$ variability, the 3-D moving window 
Multiple Linear Regression method (3-DwMLR) developed by Velo et al. (2011) was applied to try to obtain the consistent $A_{T}$ data of these cruises, defining successfully new $A_{T}$ data $\left(A_{T M L R}\right)$. In order to check if the adjustments of $A_{T M L R}$ are well done, the widely applied in CARINA secondary quality control (2nd QC) crossovers analysis (Tanhua, 5 2010; Tanhua et al., 2010a, b; Velo et al., 2010a) method was used. (2) Taking into account the $\frac{\mathrm{C}_{\mathrm{T}}}{\mathrm{A}_{\mathrm{T}}}$ ratio, the $\mathrm{C}_{\mathrm{T}}$ data were calculated using the Eq. (1):

$\mathrm{C}_{\mathrm{T}}=\frac{\mathrm{C}_{\mathrm{T} \text { orig }}}{\mathrm{A}_{\mathrm{T} \text { orig }}} \cdot \mathrm{A}_{\mathrm{TMLR}}$

Where $\mathrm{C}_{\mathrm{T} \text { orig }}$ and $\mathrm{A}_{\mathrm{T} \text { orig }}$ are the $\mathrm{C}_{\mathrm{T}}$ and $\mathrm{A}_{\mathrm{T}}$ original data for the $\mathrm{A} 06$ and $\mathrm{A} 07$ cruises and $A_{T M L R}$ is the modified data set of $A_{T}$ for the A06 and A07 cruises. Nonetheless, a little bias in $\mathrm{pH}$ profiles is slightly appreciated (Fig. 1). Therefore, the same little bias should be transfer to the $\frac{\mathrm{C}_{T}}{\mathrm{~A}_{T}}$ ratio. In order to solve this deviation, the crossover analysis method was applied to the cruises listed in Table 1, calculating $C_{T}$ data by Eq. (2):

$\mathrm{C}_{\mathrm{T}}=\frac{\mathrm{C}_{\mathrm{T} \text { orig }}}{\mathrm{A}_{\text {T orig }}} \cdot \mathrm{A}_{\mathrm{TMLR}} \cdot \mathrm{FACTOR}$

Where the factor, one for each A06 and A07 cruises, is calculated as function of the 15 value of crossover offset obtained from crossovers analysis and taking into account $2100 \mu \mathrm{mol} \mathrm{kg}{ }^{-1}$ as the mean $\mathrm{C}_{\mathrm{T}}$ value for deep water in the Atlantic Ocean.

\subsection{The 3-D moving window MLR estimation (3-DwMLR)}

$A_{T}$ is the parameter that can be computed most accurately with less uncertainty due to its low variability in the ocean. Moreover, $A_{T}$ can be well correlated with salinity, silicate, and even temperature (Wallace, 1995; Millero, 1995; Lee et al., 2006). Due to that, $A_{T}$ data can be directly used for MLR computations (Velo et al., 2011). The objective is to improve the results of a MLR by using a 3-D moving window around the node where $A_{T}$ is being calculated. An algorithm extracts a pool of data from a box around each

\section{ESSDD}

4, 99-122, 2011

Data recovery of A06 and A07 WOCE cruises

N. M. Fajar et al.

Title Page

Abstract Instruments

Data Provenance \& Structure

Tables Figures

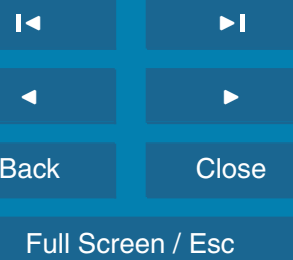

Printer-friendly Version Interactive Discussion

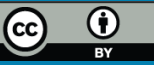


$A_{T}$ data to perform the calculation. That box is the central node of the moving window, and each $A 06$ and $A 07 A_{T}$ data have assigned their specific data window. Each data window has a particular width and depth, which have been selected according to the experience taking in Velo et al. (2010b and 2011). Thus, the unreliable quality $A_{T}$ 5 data of $A 06$ and $A 07$ has been replaced by the 3-DwMLR method, giving back the successfully fitted $A_{T M L R}$ data for A06 and A07.

\subsection{2nd QC: crossovers analysis}

Crossovers analysis is an objective comparison of deep water data from one cruise with data from other cruises in the same area, available as a MATLAB tool-box in CDIAC 10 web site (http://cdiac.ornl.gov/oceans/2nd_QC_Tool/) (Tanhua, 2010). The result of a crossover analysis is an offset \pm standard deviation, which is defined as the difference between two cruises, A (cruise will be analysed) and B (cruise as reference), derived from the analysis. This tool interpolates vertical profiles of stations from $A$ and $B$ cruises in the nearest area and calculates the "difference profile". This procedure is repeated 15 in each pair of stations and the result is a crossover offset media for each crossover pair. For $\mathrm{C}_{\mathrm{T}}, \mathrm{A}_{\mathrm{T}}$ and salinity, these offsets are quantified as an additive adjustment, while, in case of $\mathrm{O}_{2}$ and nutrient data are quantified as a lineal correction factor.

Here, the crossovers analysis has two main goals, (1) to confirm that the $A_{T M L R}$ data obtained using 3-DwMLR agree with GLODAP/CARINA quality criteria, i.e. biases not 20 greater than $\pm 6 \mu \mathrm{mol} \mathrm{kg}^{-1}$ and (2) to recover $\mathrm{C}_{\mathrm{T}}$ data (Eq. 2), to obtain a valid offset to minimize the deviation of $\frac{\mathrm{C}_{\text {Torig }}}{\mathrm{A}_{\mathrm{T} \text { orig }}}$ ratio giving a new coherent ratio.

\section{Results and discussion}

\subsection{Recovery of $A_{T}$ data}

In order to check and complete the $A_{T}$ data of both A06 and A07 cruises along the 25 Equatorial Atlantic Ocean, the 3-DwMLR method was used in this dataset. The evident improvements reached by using this method is observed in Fig. 3 , where the $A_{T}$ original 106

ESSDD

4, 99-122, 2011

Data recovery of A06 and A07 WOCE cruises

N. M. Fajar et al.

Title Page

Abstract Instruments

Data Provenance \& Structure

Tables $\quad$ Figures

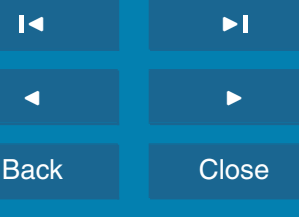

Full Screen / Esc

Printer-friendly Version

Interactive Discussion 
(Fig. 3a and b) and $A_{T M L R}$ profiles (Fig. 3c and d) of A06 and A07 cruises are shown. The Fig. $3 a$ and $b$ show the $A_{T}$ original data calculated from $\mathrm{pH}$ and $\mathrm{C}_{\mathrm{T}}$, while the $A_{T M L R}$ profiles (Fig. $3 c$ and d) show more reliable profiles for both $7.5^{\circ} \mathrm{N}$ and $4.5^{\circ} \mathrm{S}$ legs, respectively from A06 and A07 cruises. Even though the $A_{\text {Torig }}$ profiles show a 5 columnar distribution proceeding from the poor quality of $\mathrm{C}_{\mathrm{T} \text { orig }}$ measurements, there are common patterns in both $A_{T \text { orig }}$ and $A_{T M L R}$ profiles. For instance, the distribution of the upper waters is roughly similar reaching in both profiles the highest $A_{T}$ values and the influence of the bottom waters are also shared in these profiles. Moreover, the intermediate waters are also lightly correlated with the water masses present in the 10 Equatorial Atlantic Ocean. However, more realistic and clearer profiles are shown by $A_{T M L R}$ profiles for A06 and A07 cruises (Fig. 3c and d), accordingly with the horizontal and vertical distribution of the water masses in this area. Importantly the minimum of $A_{T}$ associated to the Antarctic intermediate waters is clearly shown in $A_{T M L R}$ in both A06 and A07 profiles (Fig. $3 c$ and d).

15 In order to confirm the good quality of $A_{T M L R}$ data recovered, the cruises listed in Table 1 have been used to the crossover analysis of A06 and A07. However, not all listed cruises have given an offset. The valid $A_{T M L R}$ offsets are summed up in the Table 2 together with the standard deviation and the mean offset value. The graphical representation of $\mathrm{A} 06$ and $\mathrm{A} 07 \mathrm{~A}_{\mathrm{T}}$ crossovers is shown in upper panels of Fig. 4 (Fig. 4a and $b$ ). Each point in these graphs is the offset \pm standard deviation value of cruise A (cruise crossover ID listed in Table 2) taking as reference cruise B, A06 and A07, respectively, in Fig. $4 a$ and b. In general terms, the offset value of both $A 06$ and A07 crossover analysis are not greater than $\pm 6 \mu \mathrm{mol} \mathrm{kg}^{-1}$, which is the value of $A_{T}$ data bias accepted by CARINA and GLODAP databases. The mean crossovers offset values (black bold line in Fig. $4 a$ and $b$ and the last column of $A_{T}$ in Table 2) obtained for $A_{T M L R} A 06$ and $A 07$ were $-2.1 \pm 3.7 \mu \mathrm{mol} \mathrm{kg}^{-1}$ and $-1.0 \pm 3.6 \mu \mathrm{mol} \mathrm{kg}^{-1}$, respectively. These mean offset values are also in the quality control of GLODAP and CARINA. Therefore, $A_{T M L R}$ biases are not necessary to apply. From now on, $A_{T M L R}$ data can be used as $A_{T}$ data corrected and recovered from A06 and A07 cruises.

ESSDD

4, 99-122, 2011

Data recovery of A06 and A07 WOCE cruises

N. M. Fajar et al.

Title Page

Abstract Instruments

Data Provenance \& Structure

\begin{tabular}{ll} 
Tables $\quad$ Figures \\
\hline
\end{tabular}

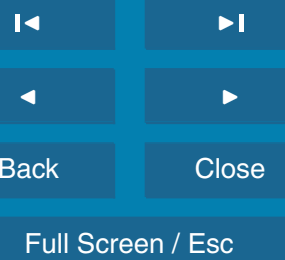

Printer-friendly Version Interactive Discussion 


\subsection{Recovery of $\mathrm{C}_{\mathrm{T}}$ data}

The $\mathrm{C}_{\mathrm{T}}$ measurements of $\mathrm{A} 06$ and $\mathrm{A} 07$ cruises are not very reliable data, as it is shown in the Fig. $5 a$ and $b$, where the distribution of $C_{T}$ lacks of continuity, even though the known patterns in surface, intermediate and bottom waters are lightly distinguished. As 5 previously said, the $\mathrm{pH}_{\text {orig }}$, calculated with $\mathrm{A}_{\mathrm{T} \text { orig }}$ and $\mathrm{C}_{\mathrm{T} \text { orig }}$, are realistic data (Fig. 1), which is an indicator of the validity of the $\frac{\mathrm{C}_{\text {Torig }}}{\mathrm{A}_{\text {Torig }}}$ ratio. In order to check how valid the $\frac{C_{T}}{A_{T}}$ ratio is, the mean $\frac{C_{T}}{A_{T}}$ profiles of both $A 06$ and $A 07$ cruises have been made. The mean profile is the mean value of the defined layers of depth. The layers from surface to $1000 \mathrm{~m}$ are calculated each $200 \mathrm{~m}$, while from $1000 \mathrm{~m}$ to bottom ( $5000 \mathrm{~m})$ each $10500 \mathrm{~m}$. The resultant mean $\frac{\mathrm{C}_{\mathrm{T}}}{\mathrm{A}_{\mathrm{T}}}$ profiles of $\mathrm{A} 06$ (continuous grey light line), A07 (continuous grey dark line) and $\mathrm{MOC}^{2}$ (black line) are shown in Fig. 6a. Bear in mind these both A06 and A07 profiles, a slight deviation of these profiles related to the MOC ${ }^{2} \frac{C_{T}}{A_{T}}$ profile is observed overall from $1000 \mathrm{~m}$ to bottom. Taking into account the recovered $A_{T}$ data $\left(A_{T M L R}\right)$ and the reliability of the $\frac{C_{T}}{A_{T}}$ ratio, $C_{T}$ was recalculated using Eq. (1), 15 and therefore, the newest $\mathrm{C}_{\mathrm{T}}$ profiles would better fit than the $\mathrm{C}_{\mathrm{T} \text { orig }}$ profiles. However, the deviation of the $\frac{C_{T}}{A_{T}}$ ratio has more influence than the corrected $A_{T M L R}$, giving the same deviated behaviour that the mean $\frac{C_{T}}{A_{T}}$ profiles. Therefore, in order to minimize that deviation a crossover analysis of $\mathrm{C}_{\mathrm{T} \text { orig }}$ is proposed.

The crossover analysis of $\mathrm{C}_{\text {Torig }}$ from $\mathrm{A} 06$ and $\mathrm{A} 07$ cruises is applied including the cruises listed in Table 1. However, idem that happened in $A_{T}$ crossover analysis, not all the cruises have given an offset. The obtained $\mathrm{C}_{\mathrm{T}}$ offsets with their corresponding standard deviation for each cruises involved in the analysis are summed up in the Table 2, and their graphical representation is shown in the Fig. 4c and d for A06 and A07 cruises, respectively. The whole offset values obtained for $C_{T} A 06$ and $A 07$ are out of the quality controls assumed by GLODAP and CARINA $\left( \pm 4 \mu \mathrm{mol} \mathrm{kg}^{-1}\right)$. The

\section{ESSDD}

4, 99-122, 2011

Data recovery of A06 and A07 WOCE cruises

N. M. Fajar et al.

\section{Title Page}

Abstract Instruments

Data Provenance \& Structure

Tables Figures

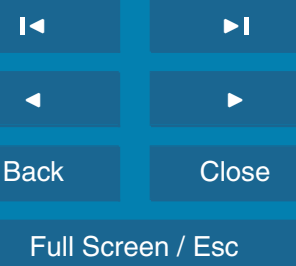

Printer-friendly Version Interactive Discussion 
$\mathrm{C}_{\mathrm{T}}$ offset values for $\mathrm{A} 06$ crossover analysis vary from -8 to $-14 \mu \mathrm{mol} \mathrm{kg}{ }^{-1}$, giving a mean offset of $-11.5 \pm 2.0 \mu \mathrm{mol} \mathrm{kg}^{-1}$, while, in case of A07 crossover analysis, the offset values vary from -4 to $-20 \mu \mathrm{mol} \mathrm{kg}^{-1}$ and their corresponding mean value is $-9.2 \pm 4.3 \mu \mathrm{mol} \mathrm{kg}^{-1}$. Taking into account the mean offset value obtained for A06 and

5 A07 crossover analysis, two factors are calculated assuming that the mean $\mathrm{C}_{\mathrm{T}}$ value in the Atlantic Ocean is $2100 \mu \mathrm{mol} \mathrm{kg}{ }^{-1}$. These factors are 1.0055 and 1.0045 for A06 and $A 07 C_{T}$ data, respectively. Using Eq. (2), the new $C_{T}$ data $\left(C_{T M L R}\right)$ for $A 06$ and A07 cruises are calculated, as it is shown in lower panels of Fig. 5 (Fig. $5 \mathrm{c}$ and d). In these figures, the reliable profiles of $\mathrm{C}_{\mathrm{TMLR}}$ are observed, showing a distribution of the 10 waters from surface to depth more homogenous than the $\mathrm{C}_{\mathrm{T} \text { orig. }}$. For example in $\mathrm{A} 07$ profile (Fig. $5 \mathrm{~d}$ ), the highest values of $\mathrm{C}_{\mathrm{T}}$ influenced by the Antarctic bottom waters are more outlined in $\mathrm{C}_{\mathrm{TMLR}}$ than $\mathrm{C}_{\mathrm{T} \text { orig }}$, as well as the minimum values of intermediate water around $2000 \mathrm{~m}$ in A06 profile (Fig. 5c).

In order to check if these corrected $C_{T M L R}$ values are really reliable, the mean $\frac{C_{T}}{A_{T}}$ 15 profiles of both $\mathrm{A} 06$ and $\mathrm{A} 07$ are calculated. In Fig. 6a, the suitability between A06 and $A 07 \frac{C_{T}}{A_{T}}$ profiles related to $M O C^{2}$ profile is shown across the grey (light and dark) dashed lines, where is clearly identified the good agreement among cruises.

\section{3 pH data}

The $\mathrm{pH}_{\text {orig }}$ data available of $\mathrm{A} 06$ and $\mathrm{A} 07$ data are not very reliable due to the unknown temperature and calibration data. Then, the $\mathrm{pH}_{\text {orig }}$ was recalculated with $\mathrm{A}_{\mathrm{T} \text { orig }}$ and $\mathrm{C}_{\text {Torig }}$ original using the $\mathrm{CO}_{2}$ sys program showing reliable profiles (Fig. 1). In order to check if $\mathrm{pH}_{\text {orig }}$ data $\mathrm{A06}$ and $\mathrm{A} 07$ are in agreement with their mate cruise in location, $\mathrm{MOC}^{2}$, the mean $\mathrm{pH}$ profiles of these cruises have been made (Fig. $6 \mathrm{~b}$ ). The mean $\mathrm{pH}$ profiles of $\mathrm{MOC}^{2}$, $\mathrm{A} 06$ and $\mathrm{A} 07$ are shown in Fig. $6 \mathrm{~b}$. In this Fig. $6 \mathrm{~b}$, the grey continuous lines (light and dark) represent $\mathrm{A} 06$ and $\mathrm{A} 07 \mathrm{pH}_{\text {orig }}$, respectively, while the black line represents $\mathrm{MOC}^{2} \mathrm{pH}$. Following the same pattern than mean $\frac{\mathrm{C}_{T}}{\mathrm{~A}_{T}}$ profiles,

\section{ESSDD}

4, 99-122, 2011

Data recovery of A06 and A07 WOCE cruises

N. M. Fajar et al.

Title Page

Abstract Instruments

Data Provenance \& Structure

\begin{tabular}{ll} 
Tables $\quad$ Figures \\
\hline
\end{tabular}

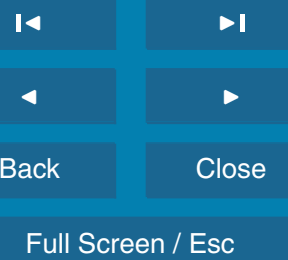

Printer-friendly Version

Interactive Discussion 
the deviation of these $\mathrm{A} 06$ and $\mathrm{A} 07$ profiles is clearly shown related to the $\mathrm{MOC}^{2} \mathrm{pH}$ profile.

In order to assert the good quality of the recovered carbon variables, i.e. $A_{T M L R}$ and $\mathrm{C}_{\mathrm{TMLR}}$, to $\mathrm{A} 06$ and $\mathrm{A} 07$ cruises, the $\mathrm{pH}_{\mathrm{MLR}}$ has been calculated. In the same way 5 than mean $\mathrm{pH}_{\text {orig }}$ profiles, the mean $\mathrm{pH}_{\mathrm{MLR}}$ profiles have been estimated, obtaining the expected coherence among $\mathrm{A} 06, \mathrm{~A} 07$ and $\mathrm{MOC}^{2}$ mean $\mathrm{pH}$ profiles, in the same way that it happens in mean $\frac{\mathrm{C}_{T}}{\mathrm{~A}_{T}}$ profiles. In Fig. $6 \mathrm{~b}$, the clear concordance between $\mathrm{A06}$ and $\mathrm{A} 07$ (light and dark grey dashed lines, respectively) and $\mathrm{MOC}^{2}$ mean $\mathrm{pH}$ profiles (black continuous line) is demonstrated. Therefore, the whole carbon database was 10 recovered from $\mathrm{A} 06$ and $\mathrm{A} 07$ cruises.

\section{Conclusions}

The recovery of $A_{T}$ and $C_{T}$ data of $A 06$ and $A 07$ cruises suggests new branches of study about the carbon distribution in the equatorial Atlantic Ocean. Taking into account the transport and the exchanges of mass, the carbon transport in that area could be estimated together with the storage of anthropogenic $\mathrm{CO}_{2}$ in 1990s. Giving a regional estimate of the accumulative oceanic sink for anthropogenic $\mathrm{CO}_{2}$ could also be done. Moreover, bear in mind the $\mathrm{MOC}^{2}$ cruise, the possibility of study the changes in anthropogenic carbon storage, calcite/aragonite horizon and $\mathrm{pH}$ from 1990 s to present times are planned as future work.

20 Taking into account this recovery of carbon data in the Atlantic Ocean, the increment in global carbon databases should be noted. The recovery and analysis of these $A_{T}$ and $\mathrm{C}_{\mathrm{T}}$ data from $\mathrm{A} 06$ and $\mathrm{A} 07$ cruises allows to future works having old references in the equatorial Atlantic Ocean because this area has never again been sampled since the 1990s WOCE cruises.

25 The innovative 3-DwMLR method applied in this work to recover $A_{T}$ in the Equatorial Atlantic Ocean could be applied to other carbon variables, and of course, in other areas
ESSDD

4, 99-122, 2011

Data recovery of A06 and A07 WOCE cruises

N. M. Fajar et al. Title Page

Abstract Instruments

Data Provenance \& Structure

Tables $\quad$ Figures

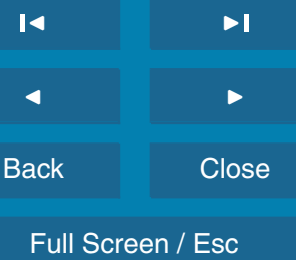

Printer-friendly Version Interactive Discussion 
of the Global Ocean being a useful tool to check and calculate data. On the other hand, the widely applied crossovers analysis is an easily and usable tool to check the quality of own data. Therefore, combining both 3-DwMLR and crossovers analysis methods could be used, as in the present work, to improve, for example, sampled and analysed data from a particular cruise and to recover data from rejected cruises.

Acknowledgements. The authors thank the hard work and dedication of analysts, investigators, and crew that collect the data at the Sea and have contributed with their data to the CARINA and GLODAP project; without them, this work would not be possible. The authors also thank the cruise participants of $\mathrm{MOC}^{2}$, both the $B I O$ Hespérides crew and the scientific and technical 10 team, for their indispensable help.

Funding for this work was provided by the 7th Framework Programme (EU FP7 CARBOCHANGE, C-ENVIR/0869) and by the Spanish Ministry of Education and Sciences through the Projects GHGMOC (CTM2009-07574-E) and MOC2 (CTM2008-06438-C02-01/MAR).

The first author is funded by a predoctoral fellowship of the program JAE "Junta para la Ampliación de Estudios" from the Spanish National Research Council (Consejo Superior de Investigaciones Científicas, CSIC).

\section{References}

Clayton, T. and Byrne, R. H.: Spectrophotometric seawater $\mathrm{pH}$ measurements: Total hydrogen ion concentration scale concentration scale calibration of $\mathrm{m}$-cresol purple and at-sea results, Deep-Sea Res. Pt. I, 40, 2115-2129, 1993.

Dickson, A. G. and Millero, F. J.: A comparison of the equilibrium constants for the dissociation of carbonic acid in seawater media, Deep-Sea Res. Pt. I, 34, 1733-1743, 1987.

Johnson, K. M., Wills, K. D., Butler, D. B., Johnson, W. K., and Wong, C. S.: Coulometric total carbon dioxide analysis for marine studies: maximizing the performance of an automated gas extraction system and coulometric detector, Mar. Chem., 17, 1-21, 1993.

Johnson, K. M., Dickson, A. G., Eischeid, G., Goyet C., Guenther, P., Key, R. M., Millero, F. J., Purkerson, D., Sabine, C. L., Schottle, R. G., Wallace, D. W. R., Wilke, R. J., and Winn, C. D.: Coulometric total carbon dioxide analysis for marine studies: assessment of the quality of

\section{ESSDD}

4, 99-122, 2011

Data recovery of A06 and A07 WOCE cruises

N. M. Fajar et al.

Title Page

Abstract Instruments

Data Provenance \& Structure

Tables $\quad$ Figures

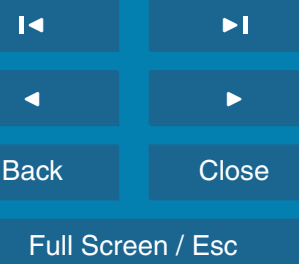

Printer-friendly Version

Interactive Discussion 
total inorganic carbon measurements made during the US Indian Ocean CO Survey 19941996, Mar. Chem., 63, 21-37, 1998.

Key, R. M., Kozyr, A., Sabine, C. L., Lee, K., Wanninkhof, R., Bullister, J., Feely, R. A., Millero, F., Mordy, C. and Peng, T. H.: A global ocean carbon climatology: Results from GLODAP, $5 \quad$ Global Biogeochem. Cy., 18, GB4031, doi:10.1029/2004GB002247, 2004.

Key, R. M., Tanhua, T., Olsen, A., Hoppema, M., Jutterström, S., Schirnick, C., van Heuven, S., Kozyr, A., Lin, X., Velo, A., Wallace, D. W. R., and Mintrop, L.: The CARINA data synthesis project: introduction and overview, Earth Syst. Sci. Data, 2, 105-121, doi:10.5194/essd-2105-2010, 2010.

10 Lee, K., Tong, L. T., Millero, F. J., Sabine, C. L., Dickson, A. G., Goyet, C., Park, G. H., Wanninkhof, R., Feely, R. A., and Key, R. M.: Global relationships of total alkalinity with salinity and temperature in surface waters of the world's oceans, Geophys. Res. Lett., 33, L19605, doi:10.1029/2006GL027207, 2006.

Lee, K., Kim, T.-W., Byrne, R. H., Millero, F. J., Feely, R. A., and Liu, Y.-M.: The universal ratio 15 of boron to chlorinity for the North Pacific and North Atlantic oceans, Geochim. Cosmochim. Ac., 74, 1801-1811, 2010.

Mehrbach, C., Culberson C. H., Hawley J. E., and Pytkowicz R. M.: Measurement of the apparent dissociation constants of carbonic acid in seawater at atmospheric pressure, Limnol. Oceanogr. 18, 897-907, 1973.

20 Millero, F. J.: Thermodynamics of the carbon dioxide system in the oceans, Geochim. Cosmochim. Ac., 59, 661-677, 1995.

Mintrop, L., Pérez, F. F., González-Davila, M., Santana-Casiano, M. J., and Kortzinger, A.: Alkalinity determination by potentiometry: Intercalibration using three different methods, Cienc. Mar., 26, 23-37, 2000.

Oudot, C.: Total $\mathrm{CO}_{2}$ and total alkalinity data obtained during the R/V L'Atalante cruise in the Atlantic Ocean, (WOCE Section A06, 2 January-10 February 1993) http://cdiac.ornl.gov/ftp/oceans/a06woce/, Carbon Dioxide Information Analysis Center, Oak Ridge National Laboratory, US Department of Energy, Oak Ridge, Tennessee, doi:10.3334/CDIAC/otg.WOCE_A06_1993, 1993a.

30 Oudot, C.: Carbon Data Obtained during the R/V L'Atalante cruise in the Atlantic Ocean (WOCE Section A07, 13 February-19 March 1993) http://cdiac.ornl.gov/ftp/oceans/a07woce/, Carbon Dioxide Information Analysis Center, Oak Ridge National Laboratory, US Department of Energy, Oak Ridge, Tennessee, doi:10.3334/CDIAC/otg.WOCE_A07_1993, 1993b.

\section{ESSDD}

4, 99-122, 2011

Data recovery of A06 and $A 07$ WOCE cruises

N. M. Fajar et al.

Title Page

Abstract Instruments

Data Provenance \& Structure

Tables $\quad$ Figures

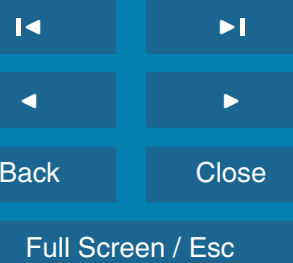

Printer-friendly Version

Interactive Discussion 
Oudot C., Ternon, J. F. and Lecomte, J.: Measurements of atmospheric and oceanic $\mathrm{CO}_{2}$ in the tropical Atlantic: 10 years fater 1982-1984 FOCAL cruises, Tellus, 47B, 70-85, 1995.

Pérez, F. F. and Fraga, F.: A precise and rapid analytical procedure for alkalinity determination, Mar. Chem., 21, 169-182, 1987.

5 Pierrot, D., Lewis, E., and Wallace, D. W. R.: MS Excel Program Developed for CO2 System Calculations. ORNL/CDIAC-105a, Carbon Dioxide Information Analysis Center, Oak Ridge National Laboratory, US Department of Energy, Oak Ridge, Tennessee, 2006.

Sabine, C. L., Key, R. M., Kozyr, A., Feely, R. A., Wanninkhof, R., Millero, F. J., Peng, T.-H., Bullister, J. L., and Lee, K.: Global Ocean Data Analysis Project: Results and Data. ORNL/CDIAC- 145, NDP-083, Carbon Dioxide Information Analysis Center, Oak Ridge National Laboratory, US Department of Energy, Oak Ridge, Tennessee, 110 pp., doi:10.3334/CDIAC/otg.ndp083, 2005.

Tanhua, T.: Matlab Toolbox to Perform Secondary Quality Control (2nd QC) on Hydrographic Data. ORNL/CDIAC-158, Carbon Dioxide Information Analysis Center, Oak Ridge National Laboratory, US Department of Energy, Oak Ridge, Tennessee, doi:10.3334/CDIAC/otg.CDIAC_158, 2010.

Tanhua, T., Steinfeldt, R., Key, R. M., Brown, P., Gruber, N., Wanninkhof, R., Perez, F., Körtzinger, A., Velo, A., Schuster, U., van Heuven, S., Bullister, J. L., Stendardo, I., Hoppema, M., Olsen, A., Kozyr, A., Pierrot, D., Schirnick, C., and Wallace, D. W. R.: Atlantic Ocean CARINA data: overview and salinity adjustments, Earth Syst. Sci. Data, 2, 17-34, doi:10.5194/essd-2-17-2010, 2010a.

Tanhua, T., van Heuven, S., Key, R. M., Velo, A., Olsen, A., and Schirnick, C.: Quality control procedures and methods of the CARINA database, Earth Syst. Sci. Data, 2, 35-49, doi:10.5194/essd-2-35-2010, 2010b.

Velo, A., Pérez, F. F., Lin, X., Key, R. M., Tanhua, T., de la Paz, M., Olsen, A., van Heuven, S., Jutterström, S., and Ríos, A. F.: CARINA data synthesis project: $\mathrm{pH}$ data scale unification and cruise adjustments, Earth Syst. Sci. Data, 2, 133-155, doi:10.5194/essd-2-133-2010, 2010a.

Velo, A., Vázquez-Rodríguez, M., Padín, X. A., Gilcoto, M., Ríos, A. F., and Pérez, F. F.: A 30 multiparametric method of interpolation using WOA05 applied to anthropogenic $\mathrm{CO}_{2}$ in the Atlantic, Sci. Mar., 74, 21-32, 2010b.

Velo, A., Pérez, F. F., Tanhua, T., Gilcoto, M., Ríos, A. F., and Key, R. M.: Total alkalinity estimation using MLR and neural network techniques, J. Marine Syst., submitted, 2011. 
Wallace, D. W. R.: Monitoring global ocean carbon inventories, Ocean Observing System Development Panel, Texas A\&M University, College Station, TX, 54 pp., 1995.

Wanninkhof, R., Peng, T.-H., Huss, B., Sabine, C. L., and Lee, K.: Comparison of inorganic carbon system parameters measured in the Atlantic Ocean from 1990 to 1998 and recommended adjustments, ORNL/CDIAC-140, 43 pp., 2003.

\section{ESSDD}

4, 99-122, 2011

Data recovery of A06 and A07 WOCE cruises

N. M. Fajar et al.

Title Page

Abstract Instruments

Data Provenance \& Structure

Tables Figures

14

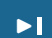

4

Back Close

Full Screen / Esc

Printer-friendly Version

Interactive Discussion

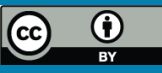


Table 1. Information about the cruises selected from combined GLODAP and CARINA database including $A 06$ and $A 07$ cruises. The cruise number is the number assigned by GLODAP or CARINA databases, Expocode is the international name for the cruise, Alias is a little name for each cruise, Year is the year when the cruise was carried out, Database is the open access database to which belong each cruise, and, in the last column, Crossovers means if the defined cruise was selected to use in crossover analysis of A06, A07 or both of them.

\begin{tabular}{|c|c|c|c|c|c|}
\hline $\begin{array}{l}\text { Cruise } \\
\text { number }\end{array}$ & Expocode & Alias & Year & Database & Crossovers \\
\hline 19 & 35A3CITHER3_2 & A13 & 1995 & GLODAP & A07 \\
\hline 20 & 35A3CITHER3_1 & A14 & 1995 & GLODAP & $\mathrm{A} 07$ \\
\hline 21 & $316 N 142 \_3$ & A15 & 1994 & GLODAP & $A 06 \& A 07$ \\
\hline 22 & OACES91_1-2 & A16Sa & 1991 & GLODAP & $\mathrm{A} 07$ \\
\hline 23 & OACES93 & $\mathrm{A} 16 \mathrm{Na}$ & 1993 & GLODAP & $A 06 \& A 07$ \\
\hline 24 & 3230CITHER2_1-2 & A17 & 1994 & GLODAP & $\mathrm{A} 06$ \& A07 \\
\hline 35 & 316N83_a,c & A12/A13 & 1983 & GLODAP & $A 06 \& A 07$ \\
\hline 43 & GEOSECS_1-9 & GEOSECS & 1972 & GLODAP & $A 06 \& A 07$ \\
\hline 46 & TTOTAS_1-3 & TTO-TAS & 1982 & GLODAP & $A 06 \& A 07$ \\
\hline 48 & 318MSAVE_1-5_HYDROS4 & SAVE & 1987 & GLODAP & $A 06 \& A 07$ \\
\hline 61 & 29HE20010305 & (FICARAM II; HE073; WOCE A17 repeat) & 2001 & CARINA & $A 06 \& A 07$ \\
\hline 62 & 29HE20020304 & (FICARAM IV; HE081; WOCE A17 repeat) & 2002 & CARINA & $\mathrm{A} 06$ \& A07 \\
\hline 84 & 33LK19960415 & (33LKETAMBOT2_1; WOCE AR04h/AR15) & 1996 & CARINA & $A 06 \& A 07$ \\
\hline 86 & 33RO20030604 & (CLIVAR A16N_2003) & 2003 & CARINA & $A 06 \& A 07$ \\
\hline 87 & 33RO20050111 & (CLIVAR A16S_2005) & 2005 & CARINA & $\mathrm{A} 07$ \\
\hline 95 & 35LU19950909 & (35LLETAMBOT1_1; WOCE AR04g) & 1995 & CARINA & $A 06 \& A 07$ \\
\hline 106 & 35TH19990712 & (35TH9907; Equalant99) & 1999 & CARINA & $A 06 \& A 07$ \\
\hline 10 & 35A3CITHER1_2 & A06 & 1993 & - & \\
\hline 11 & 35A3CITHER1_1 & $\mathrm{A} 07$ & 1993 & - & \\
\hline
\end{tabular}

Data recovery of A06 and A07 WOCE cruises

N. M. Fajar et al.

\section{Title Page}

Abstract Instruments

Data Provenance \& Structure

Tables

Figures

1

$\rightarrow 1$

4

Back

Close

Full Screen / Esc

Printer-friendly Version

Interactive Discussion 
Table 2. Results from crossover analysis applied to $A_{T M L R}$ and $C_{T \text { orig }}$ of $A 06$ and $A 07$ cruises. Cruise number is the number assigned by GLODAP or CARINA databases. Cruise Crossover ID is the identity given to each cruise in the crossover analysis. Offset and Uncertainty are the offset \pm standard deviation obtained from crossover analysis, while the mean offset is the mean value of all offsets including in each $A_{T}$ or $C_{T}$ analysis.

\begin{tabular}{|c|c|c|c|c|c|c|c|c|c|}
\hline & \multicolumn{5}{|c|}{$A_{\text {TMLR }}$} & \multicolumn{4}{|c|}{$\mathrm{C}_{\mathrm{T} \text { orig }}$} \\
\hline & $\begin{array}{l}\text { Cruise } \\
\text { number }\end{array}$ & $\begin{array}{c}\text { Cruise } \\
\text { Crossover ID }\end{array}$ & Offset & Uncertainty & $\begin{array}{c}\text { Mean } \\
\text { offset } A_{T}\end{array}$ & $\begin{array}{r}\text { Cruise } \\
\text { Crossover ID }\end{array}$ & Offset & Uncertainty & $\begin{array}{l}\text { Mean } \\
\text { offset } C_{T}\end{array}$ \\
\hline \multirow{8}{*}{ A06 } & 84 & 1 & -0.7 & 4.6 & \multirow[t]{8}{*}{-2.1} & 1 & -8.2 & 5.6 & \multirow[t]{8}{*}{-11.5} \\
\hline & 86 & 2 & 0.2 & 1.8 & & 2 & -12.6 & 1.9 & \\
\hline & 95 & 3 & -3.2 & 2.6 & & 3 & -9.8 & 3.3 & \\
\hline & 106 & 4 & -8.7 & 3.3 & & - & - & - & \\
\hline & 23 & 5 & -0.4 & 2.2 & & 4 & -13.2 & 2.0 & \\
\hline & 24 & 6 & -5.7 & 2.0 & & 5 & -11.9 & 2.5 & \\
\hline & 46 & 7 & -1.1 & 4.4 & & 6 & -13.1 & 4.3 & \\
\hline & 48 & 8 & 3.1 & 7.6 & & - & - & - & \\
\hline \multirow{11}{*}{$\mathrm{A} 07$} & 84 & 1 & -0.7 & 8.1 & \multirow[t]{11}{*}{-1.0} & 1 & -8.2 & 6.7 & \multirow[t]{11}{*}{-9.2} \\
\hline & 86 & 2 & -1.4 & 1.6 & & 2 & -5.2 & 2.8 & \\
\hline & 87 & 3 & 0.4 & 2.5 & & 3 & -8.9 & 3.7 & \\
\hline & 106 & 4 & 0.4 & 7.0 & & 4 & -9.2 & 9.1 & \\
\hline & 19 & - & - & - & & 5 & -20.7 & 4.9 & \\
\hline & 20 & 5 & -7.3 & 3.2 & & 6 & -8.0 & 3.4 & \\
\hline & 21 & 6 & 3.1 & 3.3 & & 7 & -7.2 & 2.6 & \\
\hline & 22 & 7 & 2.5 & 3.3 & & 8 & -12.2 & 1.5 & \\
\hline & 23 & - & - & - & & 9 & -4.7 & 1.8 & \\
\hline & 24 & 8 & -5.1 & 2.0 & & 10 & -7.7 & 1.9 & \\
\hline & 48 & - & - & - & & 11 & -9.8 & 10.9 & \\
\hline
\end{tabular}

4, 99-122, 2011

Data recovery of A06 and A07 WOCE cruises

N. M. Fajar et al.

\section{Title Page}

Abstract Instruments

Data Provenance \& Structure

Tables

Figures

14

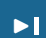

4

Back

Close

Full Screen / Esc

Printer-friendly Version

Interactive Discussion 


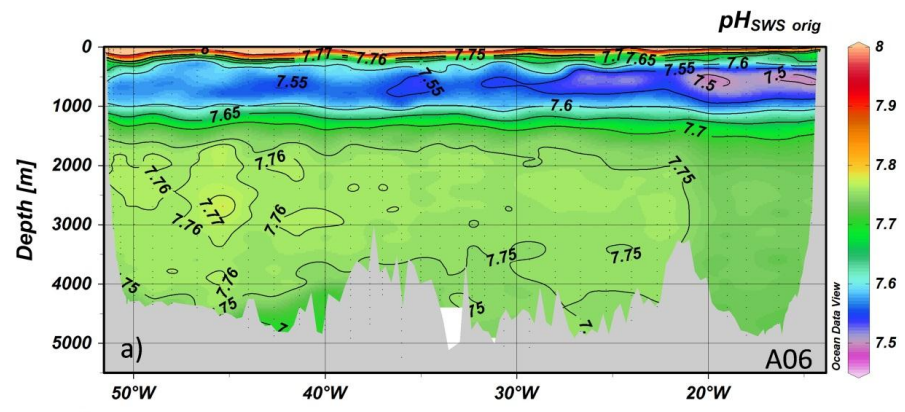

\section{ESSDD}

4, 99-122, 2011

Data recovery of A06 and A07 WOCE cruises

N. M. Fajar et al.

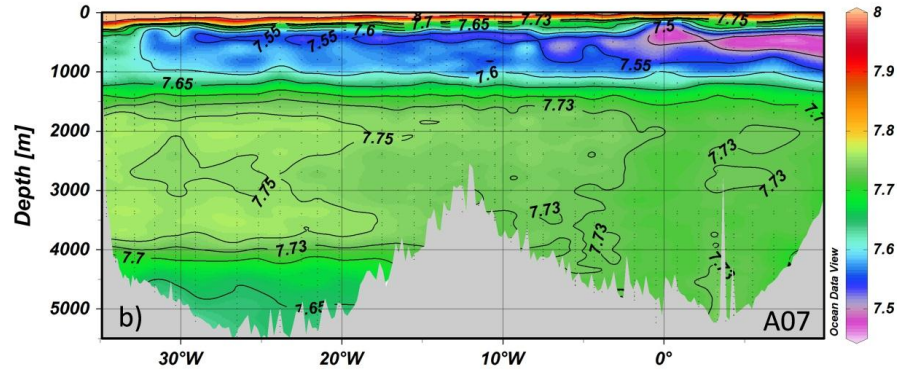

\section{Title Page}

Abstract Instruments

Data Provenance \& Structure

Tables

Figures

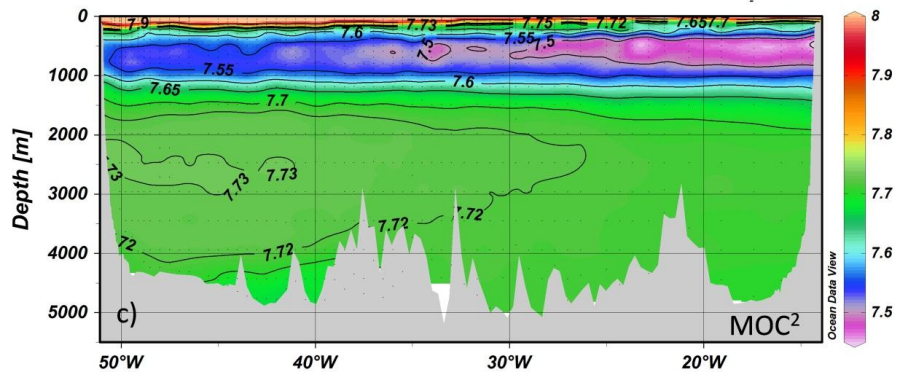
14

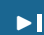
4
Back
Close
Full Screen / Esc

Printer-friendly Version

Interactive Discussion

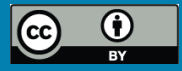




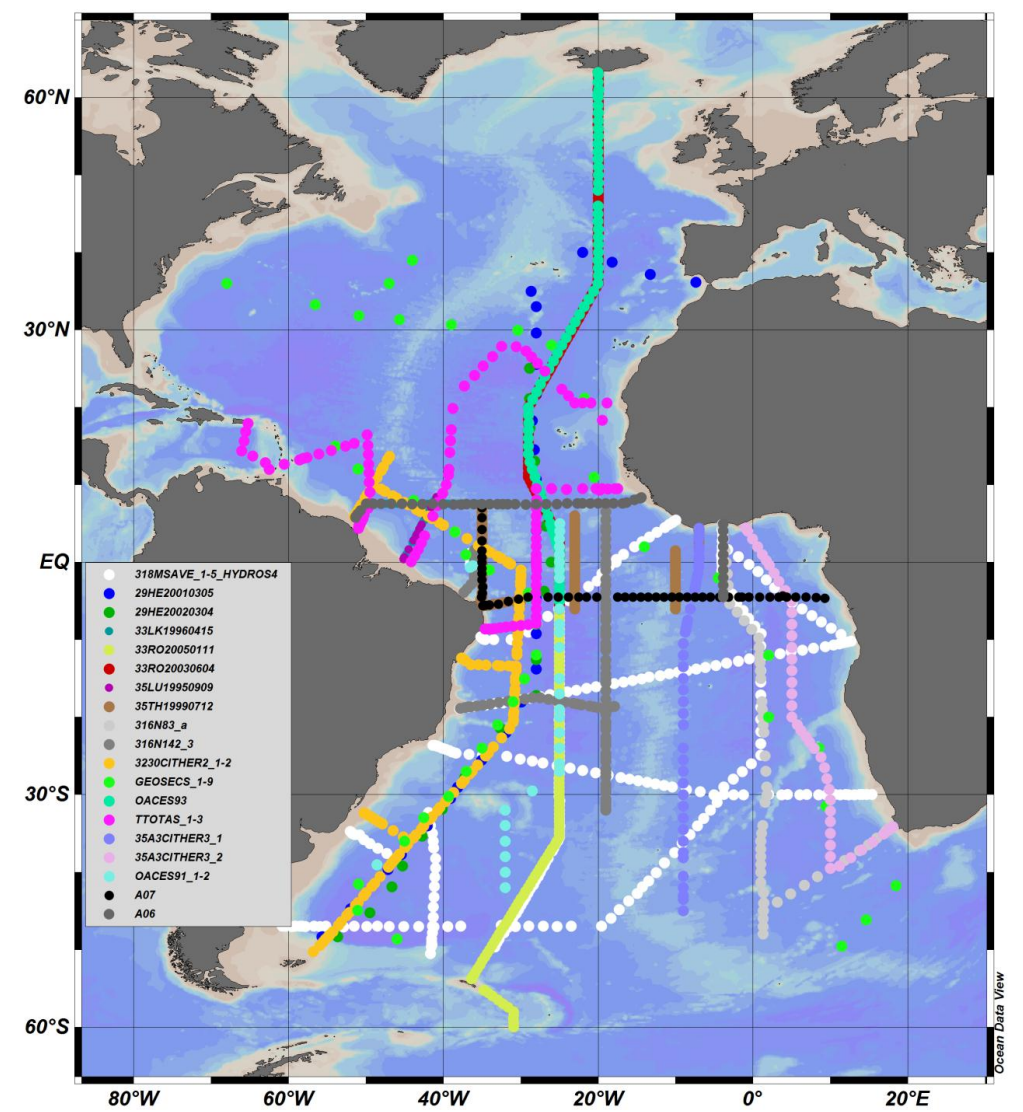

Fig. 2. Geographical distribution of selected cruises of the combined GLODAP and CARINA database carried out near A06 and A07 cruises. These both A06 and A07 cruise are also shown while $M O C^{2}$ cruise, which is not show, is a repetition of A06 stations.

\section{ESSDD}

4, 99-122, 2011

Data recovery of A06 and A07 WOCE cruises

N. M. Fajar et al.

\section{Title Page}

Abstract Instruments

Data Provenance \& Structure

Tables

Figures

14

4

Back Close

Full Screen / Esc

Printer-friendly Version Interactive Discussion

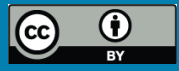



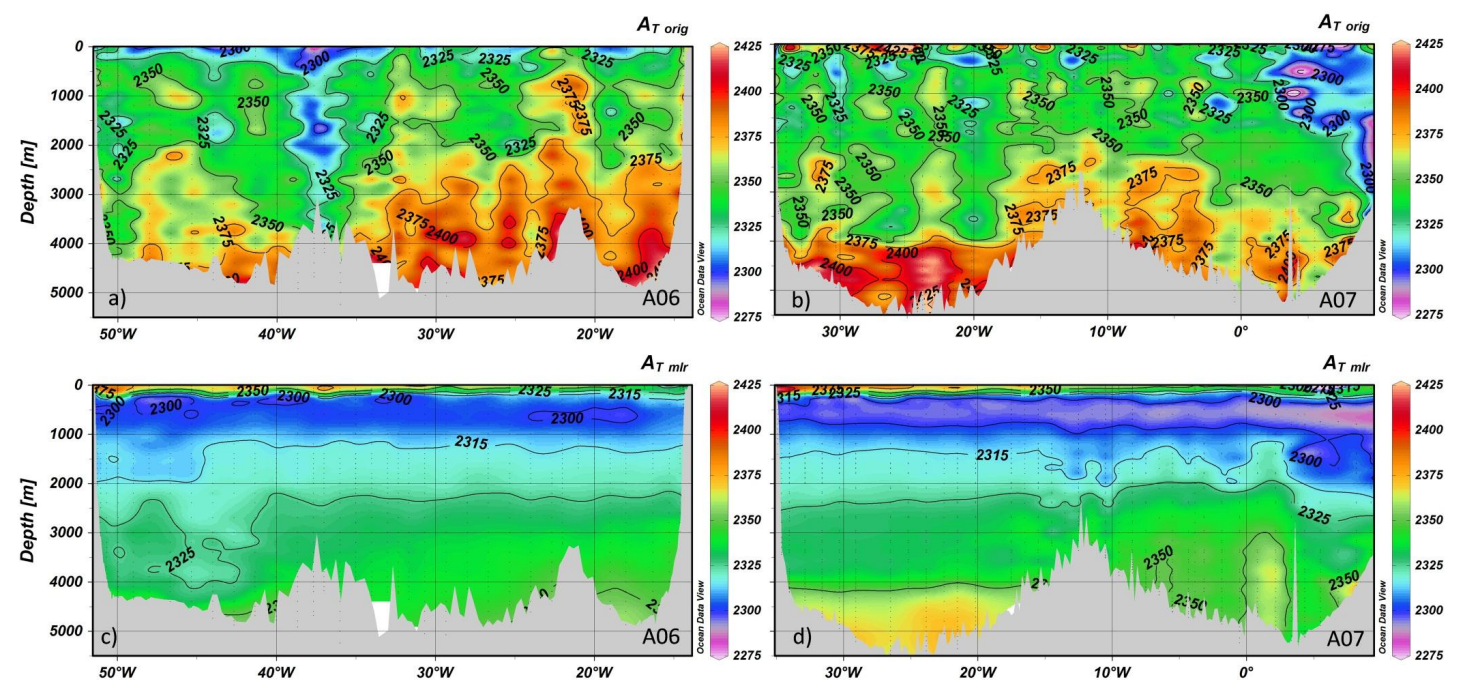

Fig. 3. $A_{T}$ data. The upper panels show the unreliable $A_{T \text { orig }}$ profiles of $A 06$ and $A 07$ cruises (a and $\mathbf{b}$, respectively) while the lower panels, (c) and (d), show the recovered $A_{T M L R}$ profiles of $\mathrm{A} 06$ and $\mathrm{A} 07$, respectively.

\section{ESSDD}

4, 99-122, 2011

Data recovery of A06 and A07 WOCE cruises

N. M. Fajar et al.

\section{Title Page}

Abstract Instruments

Data Provenance \& Structure

Tables

Figures

14

4

Back

Close

Full Screen / Esc

Printer-friendly Version Interactive Discussion

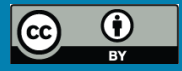


ESSDD

4, 99-122, 2011
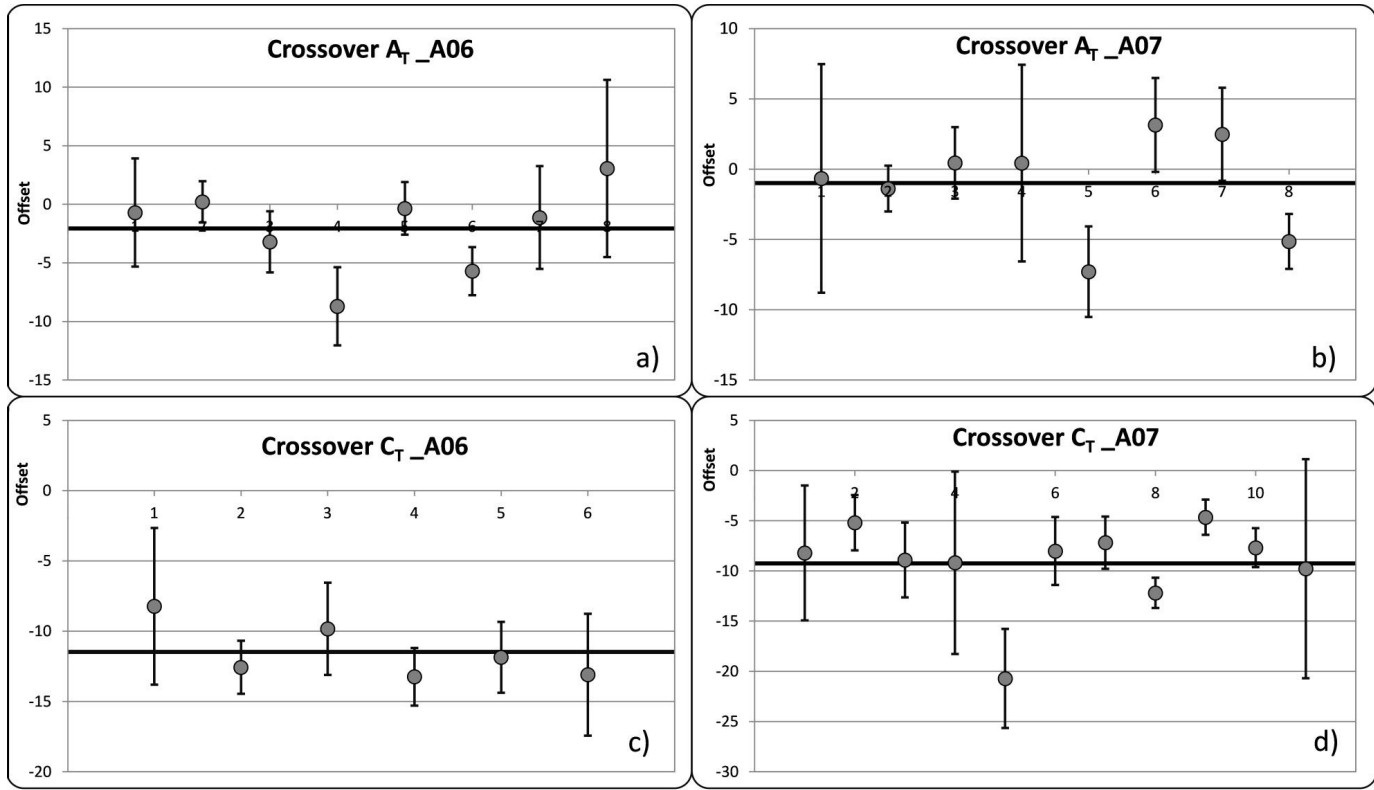

Fig. 4. Offsets obtained from crossover analysis method applied to $A_{\text {Torig }}$ (a and $\mathbf{b}$ for $A 06$ and $A 07$, respectively) and $C_{\text {Torig }}$ data (c and $\mathbf{d}$ for $A 06$ and A07, respectively). For each individual graph, the "y-axis" represents the offset value in $\mu \mathrm{mol} \mathrm{kg}^{-1}$ and the "x-axis" the crossover ID given to each cruises. Each point is the obtained offset with their associated uncertainty.
Data recovery of A06 and A07 WOCE cruises

N. M. Fajar et al.

\section{Title Page}

Abstract Instruments

Data Provenance \& Structure

\begin{tabular}{ll} 
Tables $\quad$ Figures \\
\hline
\end{tabular}

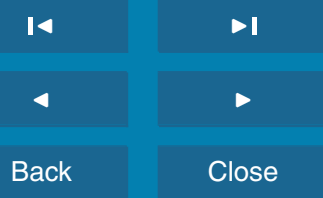

Full Screen / Esc

Printer-friendly Version

Interactive Discussion 

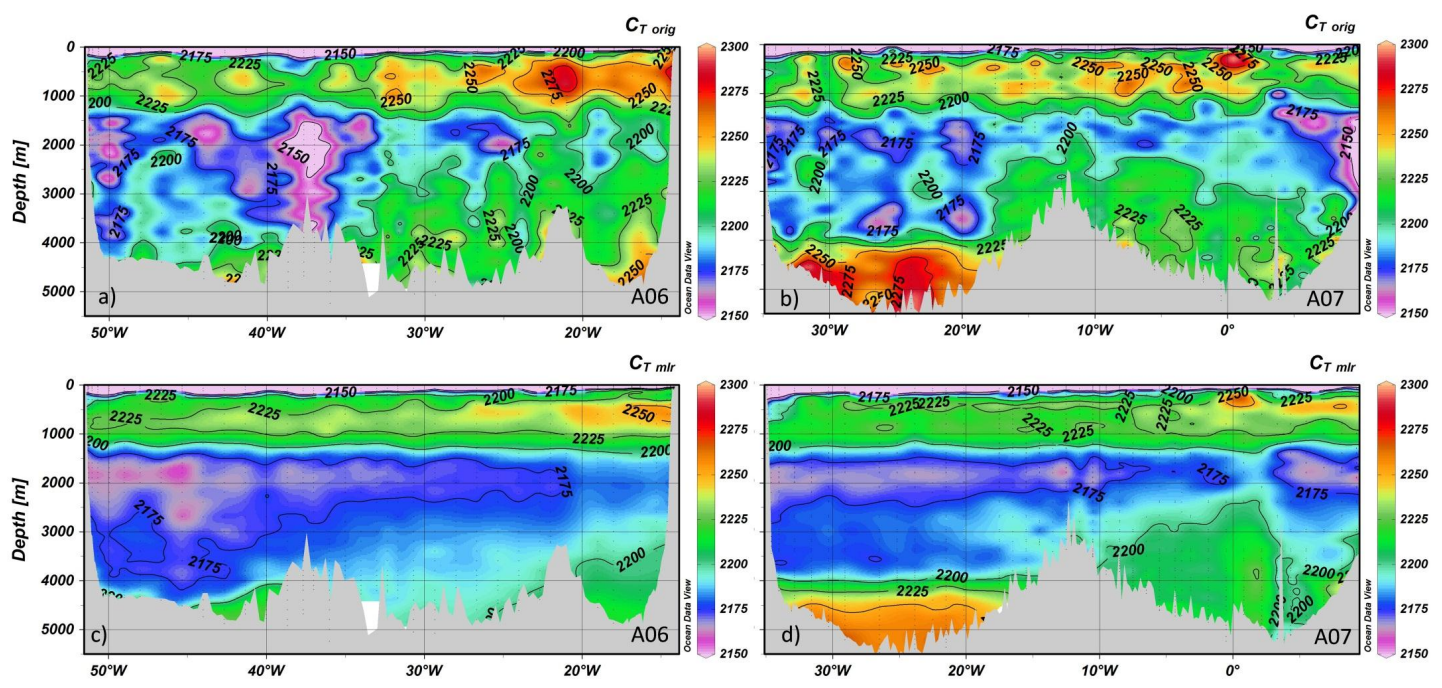

Fig. 5. $C_{T}$ data. The (a) and (b) panels show the unsuitable $C_{T \text { orig }}$ profiles of $A 06$ and $A 07$ cruises, respectively, while the (c) and (d) panels show the recovered $C_{T M L R}$ profiles of A06 and $\mathrm{A} 07$, respectively.

\section{ESSDD}

4, 99-122, 2011

Data recovery of A06 and A07 WOCE cruises

N. M. Fajar et al.

\section{Title Page}

Abstract Instruments

Data Provenance \& Structure

Tables

Figures

14

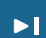

4

Back

Close

Full Screen / Esc

Printer-friendly Version Interactive Discussion

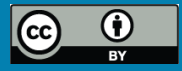



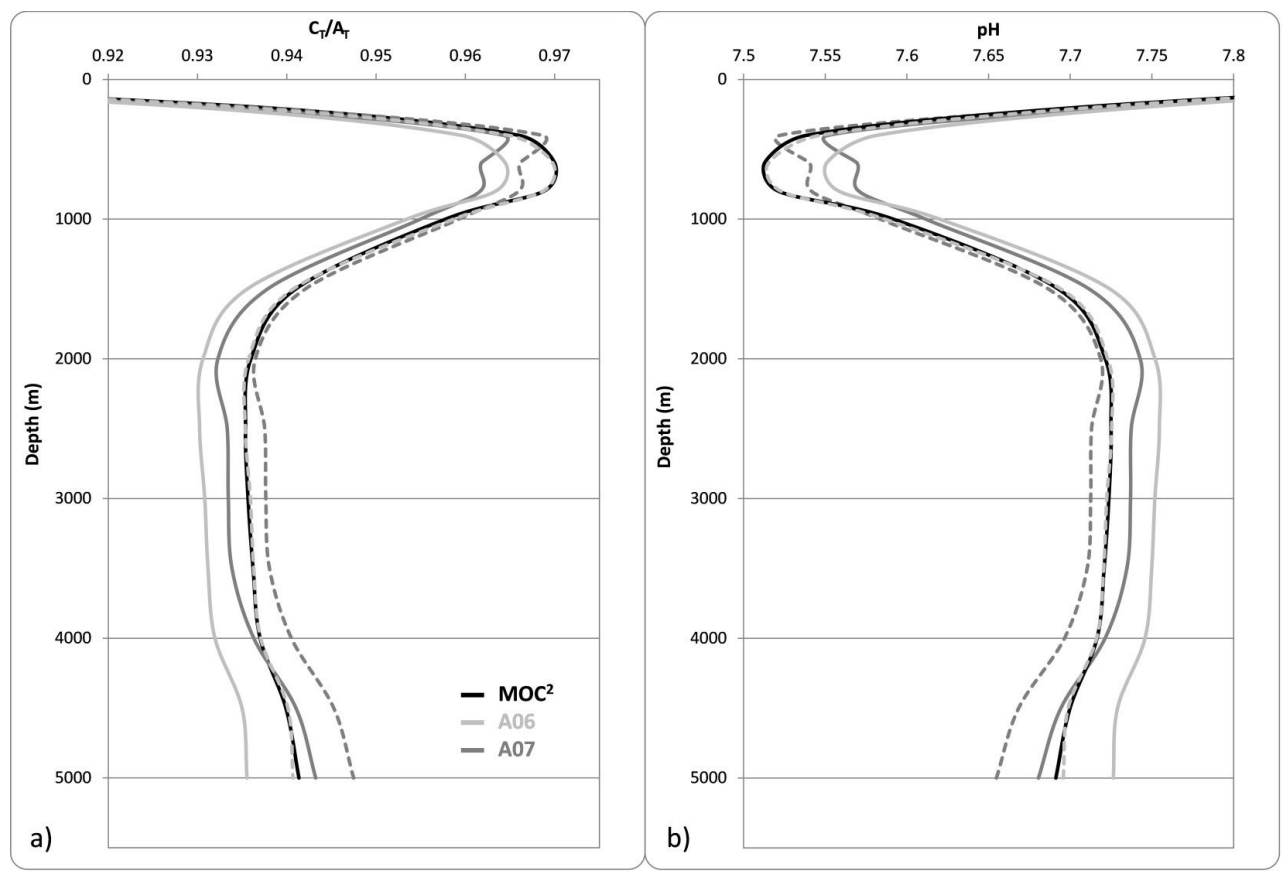

Fig. 6. Mean profiles of (a) $\frac{C_{T}}{A_{T}}$ ratio and (b) $\mathrm{pH}$ for $\mathrm{A} 06$ (light grey lines), $A 07$ (dark grey lines) and $\mathrm{MOC}^{2}$ (black lines). The $\mathrm{A} 06$ and $\mathrm{A} 07$ continuous lines display the original data, $\frac{\mathrm{C}_{\mathrm{T}} \text { orig }}{\mathrm{A}_{\mathrm{T}} \text { orig }}$ ratio and $\mathrm{pH}_{\text {orig }}$, while the dashed lines are the recovered data, $\frac{\mathrm{C}_{\mathrm{T}} \mathrm{MLR}}{\mathrm{A}_{T} \mathrm{MLR}}$ ratio and $\mathrm{pH}_{\mathrm{MLR}}$.

ESSDD

4, 99-122, 2011

Data recovery of A06 and A07 WOCE cruises

N. M. Fajar et al.

Title Page

Abstract Instruments

Data Provenance \& Structure

Tables

Figures

14

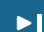

4

Back Close

Full Screen / Esc

Printer-friendly Version

Interactive Discussion

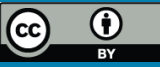

